\title{
Kebijakan Open Data Penelitian dalam Membangun Komunikasi Ilmiah di Perpustakaan Lembaga Riset
}

\author{
Tupan \\ Pusat Data dan Dokumentasi Ilmiah LIPI, Jakarta, Indonesia \\ E.mail: tupan712190@gmail.com
}

\begin{abstract}
Research on the role of research institute libraries is conducted in supporting open data research policies to improve scientific communication. The research aims at (1) To determine the role of libraries in open data research policies to improve scientific communication, (2) To determine the role of libraries in relation to the open data research movement in building scientific communication. The research was conducted using the narrative review method, which is looking for articles related to research on the role of research institute libraries in open data research policies to improve scientific communication. The results show that to improve scientific communication in research institute libraries, it is necessary to have an open data policy containing elements, namely data management plans and research data sharing processes, ensuring that data can be accessed, storing data in repositories and ensuring that data can be accessed within a certain period of time. Libraries are the pioneers of the open data research movement by providing consulting services for data analysis, research data mining, data curation services, data analysis and visualization, and saving research data over a long period of time. The main support provided by the library in building scientific communication is to create meta data and store data in repositories. Providing training in the management and storage of research data for researchers with the aim that the resulting research data can be used and disseminated for further research.
\end{abstract}

Keywords: Open Data Policy; Scientific Communication; Libraries; Research Institutes

\section{Abstrak}

Dilakukan penelitian peran perpustakaan lembaga riset dalam mendukung kebijakan open data penelitian untuk meningkatkan komunikasi ilmiah. Penelitian bertujuan untuk (1) Untuk mengetahui peran perpustakaan dalam kebijakan open data penelitian untuk meningkatkan komunikasi ilmiah, (2) Untuk mengetahui peran perpustakaan dalam kaitannya dengan gerakan open data penelitian dalam membangun komunikasi ilmiah. Penelitian

Tik Ilmeu : Jurnal Ilmu Perpustakaan dan Informasi

IAIN Curup | p-issn: 2580-3654; e-issn:2580-3662

DOI: $10.29240 /$ tik.v5i1.2514 
dilakukan dengan metode narrative review, yaitu mencari artikel yang terkait dengan penelitian peran perpustakaan lembaga riset dalam kebijakan open data penelitian untuk meningkatkan komunikasi ilmiah. Hasil penelitian menunjukkan bahwa untuk meningkatkan komunikasi ilmiah di perpustakaan lembaga riset diperlukan adanya kebijakan open data memuat elemem yaitu rencana penegeloaan data dan proses berbagi data penelitian, memastikan datanya dapat diakses, penyimpanan data dalam repositori dan memastikan data dapat diakses dalam jangka waktu tertentu. Perpustakaan menjadi pelopor gerakan open data penelitian dengan memberikan layanan konsultasi untuk analisis data, penggalian data penelitian, layanan kurasi data, menganalisis dan memvisualisasikan data, serta menyelamatkan data penelitian dalam jangka waktu yang lama. Dukungan utama yang diberikan perpustakaan dalam membangun komunikasi ilmiah adalah membuat meta data dan menyimpan data dalam repositori. Memberikan pelatihan pengelolaan dan penyimpanan data penelitian untuk para peneliti dengan tujuan agar data penelitian yang dihasilkan dapat digunakan dan didesiminasikan untuk penelitian lebih lanjut.

Kata Kunci: Kebijakan Data Terbuka; Komunikasi Ilmiah; Perpustakaan; Lembaga Riset.

\section{A. PENDAHULUAN}

Berkembang pesatnya repositori data online yang dapat diakses gratis dapat membantu peneliti untuk meningkatkan komunikasi ilmiah. Tercatat sebanyak 5601 repositori hingga Januari 2021 menurut Directory of Open Access Repository (DOAR, 2021). Repositori terbuka terbanyak adalah tipe repositori artikel jurnal sebanyak 3935 repositori, kemudian disusul repositori thesis dan disertasi sebanyak 3235 , buku seabanyak 2145 , laporan penelitian sebanyak 1866 , repositori data 382 dan repositori paten sebanyak 176 repositori.

Chiware \& Mathe (2015) mengatakan bahwa perpustakaan lembaga riset mempunyai peran untuk mengembangan dan mengintegrasikan layanan data penelitian melalui repositori, mengedukasi pengumpulan data, kurasi data penelitian kepada para peneliti. Selain itu, perpustakaan juga berperan dalam diseminasi data bentuk akses terbuka. Terbukanya akses data penelitian sangat mempengaruhi perkembangan komunikasi/kerjasama ilmiah. Pencapaian Lembaga ilmiah dievaluasi berdasarkan hasil penelitian yang diselesaikan, publikasi ilmiah dan prestasi profesional staf peneliti. Kriteria evaluasi adalah solusi organisasi dan teknologi yang memungkinkan dilakukan analisis. Dalam situasi seperti ini, kebijakan pengelolaan data oleh 
lembaga penelitian perlu dilaksanakan. Mengamankan data dari kehilangan dan menjamin aksesnya untuk generasi mendatang merupakan tantangan bagi pusat penelitian ilmu pengetahuan dan teknologi (Grygoruk, 2018). Akses terbuka ke data dapat meningkatkan transparansi proses penelitian serta mendorong kerja sama ilmiah dan pelaksanaan penelitian ilmiah lintas disiplin ilmu. Perkembangan beberapa disiplin ilmu misalnya, bioinformatika) didasarkan pada akses ke data, sedangkan bidang lain (misalnya astronomi, fisika, klimatologi) sangat terkait dengan pengumpulan dan berbagi data di tingkat global. Minat yang tumbuh dalam ketersediaan data penelitian sebagian besar terkait dengan cepat perkembangan teknologi digital. Solusi teknologi informasi modern memungkinkan pembuatan, penyimpanan, pemrosesan, dan pengiriman set data yang semakin besar (Grygoruk, 2018).

Huston et all (2019) mengatakan bahwa Open Data adalah bagian dari gerakan global yang tidak hanya memajukan ilmu pengetahuan dan komunikasi ilmiah, tetapi juga mengubah masyarakat modern dan cara pengambilan keputusan. Munculnya seruan gerakan Open Science dan munculnya jurnal online telah meluas ke gerakan open data, berdasarkan kesepakatan bahwa jika laporan data bersifat terbuka, maka data yang dihasilkan atau pendukung harus terbuka juga. Ada sejumlah kemajuan dalam Open Data selama dekade terakhir, sebagian besar dipelopori oleh pemerintah. Manfaat nyata dari Open Data tidak hanya database tunggal yang dapat digunakan secara lebih luas; data ini juga dapat dimanfaatkan, dibagikan, dan digabungkan dengan data lain. Open Data memfasilitasi kolaborasi ilmiah, memperkaya penelitian, dan memajukan kapasitas analitis untuk menginformasikan keputusan. Dalam bidang kesehatan manusia dan lingkungan misalnya, kemampuan untuk mengakses dan menggabungkan beragam data dapat memajukan deteksi sinyal dini, meningkatkan analisis dan evaluasi, menginformasikan pengembangan program dan kebijakan, meningkatkan kapasitas partisipasi publik, memungkinkan transparansi, dan meningkatkan akuntabilitas. Namun demikian, tantangan tetap ada. Sumber daya yang sangat besar diperlukan untuk membuat perubahan teknologi ke database terbuka dan dapat dioperasikan yang dapat diakses dengan protokol dan terminologi umum. Diantara penghasil dan pengguna data terjadi pergeseran yang melibatkan perubahan budaya dari menganggap database sebagai kekayaan intelektual yang dibatasi, menjadi menganggap data sebagai kebaikan bersama. Ada kebutuhan untuk mengatasi pertimbangan hukum dan etika dalam melakukan perubahan ini. Ada upaya untuk memodifikasi infrastruktur dan mengatasi masalah budaya, hukum, dan etika, yang penting untuk berbagi informasi secara adil dan efektif. Meskipun ada 
potensi besar untuk berbagi data yang terbuka, tepat waktu, adil dan langsung, akan bergantung pada seberapa efektif tantangan ini dapat ditangani.

Yoon (2017) mengatakan bahwa dalam masyarakat modern, pertumbuhan informasi terus berkembang. Kehidupan manusia telah berubah secara beragam karena perluasan volume penanganan dan distribusi informasi. Pesatnya pertumbuhan dan informasi teknologi dan komunikasi dapat menjadi pendorong produksi dan distribusi informasi di dunia maya. Informasi sangat mempengaruhi ekonomi, politik, masyarakat, budaya, dan lain lain. Seiring dengan perkembangan informasi yang terus meningkat, semua pemerintah di seluruh dunia menjadi semakin tertarik dengan adanya penyediaan informasi. Publik membutuhkan kebebasan dan kesetaraan untuk memperoleh atau memanfaatkan informasi yang diperlukan. Apalagi karena adanya kepentingan pengelolaan sistem untuk berbagi informasi, baik yang dimiliki pemerintah maupun masyarakat. Adanya pengelolaan sistem berbagi data mendorong pemerintah di seluruh dunia membuat kebijakan tentang berbagi informasi. Namun, dalam kasus lembaga penelitian, kebijakan berbagi data tidak efektif karena belum ada spesialisasi pekerjaan dan data yang dimiliki. Selain itu, data yang mereka miliki tidak dipersiapan untuk berbagi kepada umum. Kebijakan ilmu informasi untuk data terbuka pada lembaga publik seperti lembaga riset nasional perlu dilakukan. Diperlukan metode yang efektif dan efisien dalam pembuatan kebijakan data terbuka untuk lembaga penelitian nasional. Ketersediaan data terbuka hasil penelitian yang tersimpan dalam repositori dapat dianalisis pemanfaatannya untuk penelitian lebih lanjut. Kebijakan ilmu informasi untuk data terbuka pada lembaga penelitian nasional dapat dilakukan kajian dengan sistem pertukaran informasi yang dimilki.

Berdasarkan permaslahan tersebut dilakukan kajian peran perpustakaan lembaga riset dalam kebijakan open data penelitian untuk meningkatkan komunikasi ilmiah. Kajian bertujuan untuk (1) Untuk mengetahui peran kebijakan open data penelitian dalam meningkatkan komunikasi ilmiah, (2) Untuk mengetahui peran perpustakaan dalam kaitannya dengan geramunikasi ilmiah.

Penelitian dilakukan dengan metode narrative review, yaitu mencari artikel yang terkait dengan penelitian peran perpustakaan lembaga riset dalam kebijakan open data penelitian untuk meningkatkan komunikasi ilmiah. Narrative review dilakukan untuk menjawab pertanyaan sebagai berikut. Pertama, apa itu peran perpustakaan dalam kebijakan open data penelitian untuk meningkatkan komunikasi ilmiah? Kedua, peran 
perpustakaan dalam kaitannya dengan gerakan open data penelitian dalam membangun komunikasi ilmiah?

Pengumpulan data dilakukan pada Bulan Januari 2021 menggunakan menggunakan data base Scopus dan Web of Science. Penelusuran dilakukan untuk mencari materi yang relevan dengan menggunakan frase kunci: title open and data and policy OR title :scientific and communication and title : library. Hasil penelusuran yang diperoleh dipilih yang sesuai dengan permasalahan peran perpustakaan dalam mendukung kebijakan data penelitian untuk meningkatkan komunikasi ilmiah. Dari artikel yang terpilih disusun hasil dan pembahasan sesuai dengan pertanyaan yang diajukan menggunakan narrative review.

\section{B. HASIL DAN PEMBAHASAN}

Berdasarkan hasil pencarian data melalui Scopus dan Web of Science diperoleh17 artikel yang sesuai dengan tujuan penelitian untuk dilakukan analisis narative review. Hasil analisis artikel menghasilkan tiga tema utama yaitu peran kebijakan open data penelitian untuk meningkatkan komunikasi ilmiah, peran perpustakaan dalam gerakan open data penelitian serta dukungan perpustakaan dalam membangun komunikasi ilmiah lewat open data penelitian.

\section{Peran Kebijakan open data penelitian untuk meningkatkan komunikasi ilmiah}

Hasil telaah peran kebijakan open data dalam meningkatakan komunikasi ilmiah terdiri 6 artikel. Hasil telah lieratur seperti pada tabel 1 kemudian dianalisis dalam bentuk pembahsan dengan menggunkan narative review.

Tabel 1. Hasil Telaah Peran Kebijakan open data

\begin{tabular}{|c|c|c|}
\hline Penulis & Literatur yang ditelaah & Hasil Telaah Literatur \\
\hline Lasthiotakis (2015) & $\begin{array}{l}\text { Mengembangkan kebijakan } \\
\text { untuk memastikan bahwa data } \\
\text { yang dihasilkan dari penelitian } \\
\text { yang didanai oleh dana publik } \\
\text { harus dibagikan dengan tujuan } \\
\text { untuk meningkatkan dampak } \\
\text { dan pemanfaatannya. }\end{array}$ & $\begin{array}{l}\text { Kebijakan pengelolaan data } \\
\text { mencakup rencana } \\
\text { pengelolaan data, kualitas dan } \\
\text { standar data, dokumentasi } \\
\text { data, metode berbagi } \\
\text { data/preservasi data, waktu } \\
\text { berbagi data dan retensi data. } \\
\text { Adanya kebijakan ini dapat } \\
\text { meningkatkan komunikasi } \\
\text { ilmiah. }\end{array}$ \\
\hline Borgerud & Memberikan argumen bahwa & Open data dapat memfasilitasi \\
\hline
\end{tabular}




\begin{tabular}{|c|c|c|}
\hline Borglund (2020) & $\begin{array}{l}\text { data terbuka (open data) dapat } \\
\text { memfasilitasi r verifikasi } \\
\text { penelitian dan meningkatkan } \\
\text { transparansi. }\end{array}$ & $\begin{array}{l}\text { penggunaan kembali data di } \\
\text { studi baru, yang dapat } \\
\text { mempercepat inovasi, serta } \\
\text { membuat kolaborasi lebih } \\
\text { mudah. }\end{array}$ \\
\hline Ashiq et all (2020) & $\begin{array}{l}\text { Praktek dan layanan } \\
\text { manajemen data penelitian }\end{array}$ & $\begin{array}{l}\text { Perlu menyiapkan kebijakan } \\
\text { Nasional yang mencakup } \\
\text { tempat penyimpanan data } \\
\text { penelitian, memitigasi data, } \\
\text { menghindari dulikasi dan } \\
\text { membatu proses penerbitan } \\
\text { terbuka }\end{array}$ \\
\hline $\begin{array}{l}\text { Zuiderwijk, A., \& } \\
\text { Janssen, M. (2014) }\end{array}$ & $\begin{array}{l}\text { Kebijakan data terbuka, } \\
\text { implementasi dan dampaknya }\end{array}$ & $\begin{array}{lrr}\text { Kebijakan data } & \text { terbuka } \\
\text { yang sudah ada perlu } & \text { dengan } \\
\text { ditingkatkan } & & \text { dengan } \\
\text { berkolaborasi } & \text { dengan } \\
\text { organisasi lain } & \text { yang } \\
\text { berfokus pada dampak } & \text { Merangsang } \\
\text { kebijakan. } & \text { Meran } \\
\text { penggunaan data terbuka } \\
\text { dan melihat kebutuhan } \\
\text { dalam menciptakan budaya } \\
\text { di mana mempublikasikan } \\
\text { data adalah proses kerja } \\
\text { sehari-hari. Diperlukan } \\
\text { penyempurnaan } \\
\text { pengembangan kebijakan } \\
\text { data terbuka yang sudah } \\
\text { dikembangkan sebelumnya. }\end{array}$ \\
\hline $\begin{array}{l}\text { Mauthner and Parry } \\
\text { (2013) }\end{array}$ & $\begin{array}{l}\text { Prinsip, kebijakan dan praktek } \\
\text { bergagi data digital melalui } \\
\text { akses terbuka }\end{array}$ & $\begin{array}{l}\text { Kebijakan akses terbuka ke } \\
\text { data penelitian telah } \\
\text { dikembangankan oleh seluruh } \\
\text { organisasi pendanaan. } \\
\text { Penyandang dana mewajibkan } \\
\text { kepada semua peneliti untuk } \\
\text { melakukan berbagi data. } \\
\text { Kebijkan yang dilakukan fokus } \\
\text { pada infrastruktur, } \\
\text { metodologis, hukum, ilmiah } \\
\text { dan teknologi }\end{array}$ \\
\hline Grygoruk ( 2018) & $\begin{array}{lr}\text { Data } & \text { terbuka } \\
\text { komunikasi ilmiah }\end{array}$ & 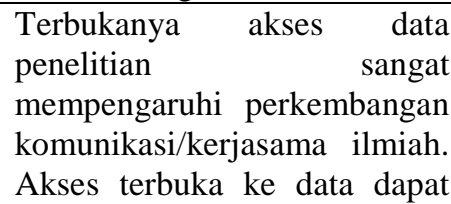 \\
\hline
\end{tabular}




\begin{tabular}{|l|l|l|}
\hline & $\begin{array}{l}\text { meningkatkan transparansi } \\
\text { proses penelitian serta } \\
\text { mendorong kerja sama ilmiah } \\
\text { dan pelaksanaan penelitian } \\
\text { ilmiah lintas disiplin ilmu }\end{array}$ \\
\hline
\end{tabular}

Menurut Lasthiotakis (2015) mengatakan bahwa dewan penelitian di Amerika Serikat dan Inggris telah mengembangkan program dan kebijakan khusus untuk memastikan bahwa data yang dihasilkan dari penelitian yang didanai oleh dana publik harus dibagikan dengan tujuan untuk meningkatkan dampak dan pemanfaatannya. Elemen kebijakan untuk berbagi menurut Lasthiotakis (2015) yang dapat meningkatkan kominikasi ilmiah mencakup beberapa elemen seperti terlihat pada tabel 1. Berikut:

Tabel 2. Elemen Kebijakan Berbagi data

\begin{tabular}{|l|l|}
\hline Elemen kebijakan & Deskripsi \\
\hline Rencana pengeloaan data & $\begin{array}{l}\text { Rencana pengeloaan data dicantumkan dalam proposal } \\
\text { pendanaan dan mengharuskan peneliti untuk menjelaskan } \\
\text { bagaimana mereka akan mengelola dan membagi datanya }\end{array}$ \\
\hline Kualitas dan standar data & $\begin{array}{l}\text { Mematuhi standar internasional atau memastikan datanya } \\
\text { dapat diakses oleh orang lain }\end{array}$ \\
\hline Dokumentasi data & $\begin{array}{l}\text { Doukentasi data dan metadata disertakan dalam data } \\
\text { sehingga data dipahami oleh orang lain }\end{array}$ \\
\hline $\begin{array}{l}\text { Metode berbagi data/ } \\
\text { preservasi data }\end{array}$ & $\begin{array}{l}\text { Menyimpan data dalam repositori, jika tidak memiliki } \\
\text { repositori data disimpan di web atau menyimpan data dalam } \\
\text { tempat lain agar data dapat tersedia bagi peneliti jika diminta }\end{array}$ \\
\hline Waktu berbagi data & $\begin{array}{l}\text { Memastikan data dapat diakses dalam jangka waktu tertentu } \\
\text { setelah publikasi hasil penelitian }\end{array}$ \\
\hline Retensi data & $\begin{array}{l}\text { Mengharapkan kepada peneliti untuk menyimpan data } \\
\text { selama minimal beberapa tahun }\end{array}$ \\
\hline
\end{tabular}

Sumber : Lasthiotakis (2015)

Mengacu pada pendapat Lasthiotakis (2015) bahwa untuk meningkatkan komunikasi ilmiah di perpustakaan lembaga riset diperlukan adanya kebijakan open data penelitian. Kebjikan open data mencakup beberapa elemem yaitu rencana penegeloaan data dan cara berbagi data, memastikan datanya dapat diakses oleh orang lain, menyimpan data dalam repositori dan memastikan data dapat diakses dalam jangka waktu tertentu. Data yang disimpan dalam repositori dan mudah diakses dapat meningkatkan komunikasi ilmiah.

Borgerud and Borglund (2020) mengatakan bahwa argumen yang mendukung open data adalah untuk memfasilitasi verifikasi penelitian dan meningkatkan transparansi. Open data dapat memfasilitasi penggunaan kembali data di studi baru, yang dapat mempercepat inovasi, serta membuat 
kolaborasi lebih mudah. Datanya juga lebih terlihat, yang dapat mendorong eksploitasi yang lebih tinggi. Penekankan penggunaan kembali data penelitian yang sudah selesai dapat hemat biaya karena hasil di masa lalu dapat dipelajari dan dianalisis tanpa mengumpulkan bahan yang sama lagi. Data penelitian terbuka dapat digunakan kembali untuk uji generalisasi, dan hasilnya dapat dibandingkan dengan menggunakan konteks, variabel, atau wilayah geografis lain. Metode penelitian baru mungkin akan muncul yang dapat diterapkan pada data penelitian yang lama. Data penelitian juga dapat digunakan dalam pengajaran mahasiswa yang berkonsentrasi pada analisis data dari pada mengumpulkannya. Dapat disimpulkan bahwa membuat data penelitian yang dapat diakses secara terbuka dapat meningkatkan penggunaan kembali data yang meningkatkan transparansi. Dari pendapat Borgerus and Borglund (2020) dapat disimpulkan bahwa open data (data terbuka) dapat meningkatkan komunikasi ilmiah diantara para peneliti dengan cara berbagi data maupun penggunaan kembali data penelitian yang telah dilakukan.

Ashiq et all (2020) mengatakan bahwa komunikasi ilmiah dapat ditingkatkan melalui penerapan kebijakan nasional yang mencakup kebijakan tempat penyimpanan data penelitian, kebijakan mitigasi data, menghindari dulikasi dan kebijakan proses penerbitan terbuka. Dari pendapat Zuiderwijk \& Janssen (2014) dapat dikatakan bahwa kebijakan data terbuka yang sudah ada dapat ditingkatkan dengan berkolaborasi dengan organisasi lain. Kebijakan data terbuka dapat merangsang penggunaan data sebagai kebutuhan serta menciptakan budaya kepada para peneliti bahwa mempublikasikan data adalah proses kerja sehari-hari. Pengembangan kebijakan data terbuka harus selalu diperbarui dengan menyempurnakan kebijakan data terbuka yang sudah ada. Mauthner and Parry (2013) kebijakan yang dilakukan untuk meningkatkan komunikasi ilmiah adalah kebijakan akses terbuka ke data penelitian yang dikembangankan oleh seluruh organisasi pendanaan. Penyandang dana mewajibkan kepada semua peneliti untuk melakukan berbagi data. Kebijakan yang dilakukan fokus pada infrastruktur, metodologis, hukum, ilmiah dan teknologi.

\section{Peran perpustakaan dalam gerakan open data penelitian}

Hasil telaah literatur tentang peran perpustakaan dalam gerakan open data penelitian diasajikan pada tabel 3 berikut.

Tabel 3. Peran perpustakaan dalam gerakan open data penelitian

\begin{tabular}{|l|l|l|}
\hline Penulis & Literatur yang ditelaah & Hasil Telaah Literatur \\
\hline Chiware (2020) & Peran perpustakaan akademik & Ada empat yang harus \\
& dan lembaga penelitian dalam & dikelola oleh perpustakaan \\
& mengelola data penelitian & untuk mendukung gerakan \\
\hline
\end{tabular}




\begin{tabular}{|c|c|c|}
\hline & & $\begin{array}{l}\text { ilmu pengetahuan terbuka } \\
\text { adalah akses dan penerbitan } \\
\text { akses terbuka, RDM, } \\
\text { infrastruktur e research dan } \\
\text { zitizen science }\end{array}$ \\
\hline OECD( 2015) & $\begin{array}{lr}\text { Perpustakaan } & \text { telah } \\
\text { mengambil peran pelestarian, } & \\
\text { kurasi, publikasi, dan } & \text { diseminasi materi ilmiah } \\
\text { digital, dalam } & \text { bentuk } \\
\text { publikasi, data, dan penelitian } & \\
\text { terkait lainnya. }\end{array}$ & $\begin{array}{l}\text { Perpustakaan dan repositori } \\
\text { merupakan infrastruktur fisik } \\
\text { yang memungkinkan para } \\
\text { ilmuwan untuk berbagi, } \\
\text { menggunakan dan } \\
\text { menggunakan kembali hasil } \\
\text { data penelitian yang penting } \\
\text { dalam penciptaan gerakan } \\
\text { ilmu pengetahuan terbuka }\end{array}$ \\
\hline $\begin{array}{l}\text { Frederick and Run } \\
(2019)\end{array}$ & $\begin{array}{l}\text { Peran perpustakaan akademik } \\
\text { dalam pengelolaan data } \\
\text { penelitian }\end{array}$ & $\begin{array}{lr}\text { Perputakaan } & \text { akademik } \\
\text { membangun penyimpanan } \\
\text { kelembagaan data penelitian. } \\
\text { Perpustakaan membuat } \\
\text { kebijakan data terbuka sebagai } \\
\text { peran baru }\end{array}$ \\
\hline Cox et all (2019) & $\begin{array}{l}\text { Peran perpustakan Perguruan } \\
\text { Tinggi dalam transformasi } \\
\text { dan peningkatan layanan data } \\
\text { penelitian }\end{array}$ & $\begin{array}{lr}\text { Perpustakaan memberikan } \\
\text { layanan konsultasi untuk } \\
\text { analisis data, penggalian data, } \\
\text { dan layanan untuk } \\
\text { membersihkan } & \text { data, } \\
\text { menganalisis dan } & \text { memvisualisasikan data, dan } \\
\text { menyelamatkan data lama } & \\
\text { masih relatif jarang. }\end{array}$ \\
\hline Wessels et al ( 2017) & $\begin{array}{l}\text { Membuat kebijakan untuk } \\
\text { memastikan dan menjelaskan } \\
\text { bagaimana jenis data } \\
\text { penelitian dibuat terbuka }\end{array}$ & $\begin{array}{l}\text { Perpustakaan menyipakan } \\
\text { repositori online untuk } \\
\text { penyimpanan data penelitian } \\
\text { sesuai dengan format standar } \\
\text { yang dapat diakses secara } \\
\text { terbuka, distribusi tidak } \\
\text { terbatas, interoperabilitas, dan } \\
\text { pengarsipan jangka panjang }\end{array}$ \\
\hline
\end{tabular}

Chiware (2020) mengatakan bahwa peran perpustakaan akademik dan penelitian di masa depan dalam mengelola data penelitian terbuka haruslah dibingkai dalam konteks sains terbuka yang lebih luas. Dari poin tersebut menunjukkan bahwa ada empat bidang yang harus dikelola perpustakaan untuk mendukung ilmu pengetahuan terbuka, yaitu akses terbuka dan penerbitan akses terbuka, $\mathrm{RDM}$, infrastruktur $e$ research dan zitizen science. Organisasi untuk kerja sama ekonomi dan pengembangan (OECD) mencatat bahwa Perpustakaan telah menyesuaikan perannya dan kini aktif dalam pelestarian, kurasi, publikasi, dan diseminasi materi ilmiah 
digital, dalam bentuk publikasi, data, dan penelitian terkait lainnya. Perpustakaan dan repositori merupakan infrastruktur fisik yang memungkinkan para ilmuwan untuk berbagi, menggunakan dan menggunakan kembali hasil data penelitian sangat penting dalam penciptaan gerakan ilmu pengetahuan terbuka (OECD, 2015)

Frederick and Run (2019)Penemuan tersebut didasarkan pada peran perpustakaan akademik dalam pengelolaan data penelitian di antara universitas-universitas di Ghana. Dari data yang didapat terlihat jelas bahwa beberapa perpustakaan akademik sudah mulai membangun penyimpanan data kelembagaan. Ini akan membantu memenuhi kebutuhan penyimpanan dan pengambilan lembaga mereka dan itu akan membawa inovasi dalam layanan perpustakaan akademik. Dalam acara perpustakaan kebijakan data terbuka profesional telah menyatakan untuk menanamkan itu sebagai peran baru. Beberapa responden setuju bahwa inovasi itulah yang menyebabkan kebijakan RDM menjadi tidak pasti. Selain itu, sekitar 35 (43\%) responden memberikan bukti bahwa beberapa Perpustakaan Akademik memiliki kebijakan kelembagaan tentang RDM. Hal ini membuat Pustakawan mencari keuntungan untuk mengklaim peran inti dalam RDM.

Pustakawan tidak perlu menunggu kebijakan tentang pengelolaan data penelitian, tetapi harus membangun pengalaman yang memungkinkan pustakawan memulai pengelolaan data penelitian. Terlepas dari inovasi yang tidak menentu, Pustakawan berusaha mengadopsi inovasi baru tersebut dengan membekali diri dengan pelatihan mengenai pengelolaan data penelitian.

Data penelitian adalah data yang digunakan sebagai dasar untuk penelitian. Komunitas kebijakan data penelitian terbuka mengacu pada Deklarasi Berlin, yang menyatakan bahwa kontribusi akses terbuka meliputi hasil penelitian ilmiah asli, data mentah dan metadata, bahan sumber informasi, representasi digital dari bahan bergambar dan grafis serta bahan multimedia ilmiah. Pembuat kebijakan memastikan dan menjelaskan bagaiamana jenis data penelitian dibuat terbuka. Pada poin ini dijelaskan bahwa dalam deklarasi untuk akses terbuka, yang menyatakan bahwa penulis dan pemegang hak harus memberi pengguna akses gratis ke materi, termasuk lisensi untuk menyalin, menggunakan, mendistribusikan, dan menampilkan materi tersebut, dengan tunduk pada atribusi yang tepat dari penulis. dan penggunaan yang bertanggung jawab. Selanjutnya, data perlu dikurasi sebagai versi lengkap dari karya tersebut, dalam format standar yang sesuai dan dikirimkan ke repositori online dengan standar teknis yang sesuai yang 
memungkinkan akses terbuka, distribusi tidak terbatas, interoperabilitas, dan pengarsipan jangka panjang (Wessels et al, 2017)

Cox et all (2019) mengatakan bahwa yang harus dilakukan perpustakaan dalam gerakan open data penelitian adalah memberikan layanan konsultasi untuk analisis data, penggalian data penelitian, layanan kurasi data, menganalisis dan memvisualisasikan data, serta menyelamatkan data penelitian dalam waktu yang lama.

\section{Dukungan Perpustakaan Dalam Membangun komunikasi ilmiah lewat open data penelitian}

Dari hasil penelusuran diperoleh 6 artikel yang sesuai dengan dukungan perpustakaan dalam membangun komunikasi ilmiah lewat open data penelitian. Hasil telaah literatur disajikan seperti pada tabel 4. berikut.

Tabel 4. Dukungan perpustakaan riset dalam membangun komunikasi ilmiah lewat open data penelitian

\begin{tabular}{|c|c|c|}
\hline Penulis & Literatur yang ditelaah & Hasil Telaah Literatur \\
\hline Hosain et all (2016) & $\begin{array}{l}\text { Perpustakaan memberikan } \\
\text { dukungan dengan menawarkan } \\
\text { paradigma baru dengan } \\
\text { mengembangkan data terbuka }\end{array}$ & $\begin{array}{l}\text { Open data (data terbuka) } \\
\text { dapat meningkatkan } \\
\text { komunikasi ilmiah karena } \\
\text { akses terbuka, mengurangi } \\
\text { duplikasi penelitian, } \\
\text { pelestarian data jangka } \\
\text { panjang, dan efisiensi biaya. }\end{array}$ \\
\hline Koltay (2019) & $\begin{array}{l}\text { Peneliti membutuhkan } \\
\text { dukungan terkait data untuk } \\
\text { seluruh siklus hidup data } \\
\text { penelitian mulai dari } \\
\text { perencanaan, } \\
\text { pengorganisasian, } \\
\text { pendokumentasian, berbagi, } \\
\text { dan pelestarian kumpulan data }\end{array}$ & $\begin{array}{l}\text { Pustakawan yang ada di } \\
\text { perpustakaan } r \text { harus } \\
\text { mempunyai kemampuan } \\
\text { untuk menemukan, } \\
\text { mengekstrak, mengumpulkan, } \\
\text { membersihkan, mengatur, } \\
\text { menganalisis, dan menyajikan } \\
\text { data. }\end{array}$ \\
\hline Liah ((2017) & $\begin{array}{l}\text { Teknik penyebaran informasi } \\
\text { untuk meningkatkan } \\
\text { komunikasi ilmiah }\end{array}$ & $\begin{array}{l}\text { Perpustakaan } \\
\text { yang mendorong akses ke } \\
\text { pengetahuan akan } \\
\text { mempercepat pembangunan } \\
\text { ekonomi, membangun } \\
\text { hubungan yang lebih kuat } \\
\text { antara penyedia informasi dan } \\
\text { masyarakat luas. }\end{array}$ \\
\hline $\begin{array}{l}\text { Hanneke and Link, } \\
\text { (2019) }\end{array}$ & $\begin{array}{l}\text { Kompleksitas dalam berbagi } \\
\text { data penelitian }\end{array}$ & $\begin{array}{l}\text { Perpustakaan memberikan } \\
\text { dukungan dalam membangun } \\
\text { komunikasi ilmiah lewat open } \\
\text { data penelitian }\end{array}$ \\
\hline Shelly \& Jackson, & Peran perpustakaan & Perpustakaan menyediakan \\
\hline
\end{tabular}




\begin{tabular}{|l|l|l|}
\hline (2018) & pengelolaan data penelitian & $\begin{array}{l}\text { dan mendorong open akses } \\
\text { data penelitian }\end{array}$ \\
\hline Charbonneau (2013) & $\begin{array}{l}\text { Strategi pengelolaan data } \\
\text { penelitian }\end{array}$ & $\begin{array}{l}\text { Perpustakaan memberikan } \\
\text { dukungan dalam membangun } \\
\text { komunikasi ilmiah melalui } \\
\text { pengembangan sistem dan } \\
\text { proses berbagi data penelitian }\end{array}$ \\
\hline
\end{tabular}

Menurut Hosain et all (2016) berkembangnnya jaringan seluler, perangkat seluler, dan perkembangan web di berbagai bidang, termasuk industri, pemerintah, perusahaan swasta, dan komunitas riset, menawarkan lebih banyak transparansi melalui rilis data pnelitian. Upaya yang dilakukan perpustakaan pada tahap awal adalah memberikan dukungan dengan menawarkan paradigma baru data terbuka. Akses data penelitian secara terbuka memberikan keuntungan bagi institusi dan komunitas dalam hal (a) mempercepat penelitian melalui akses yang lebih baik pada karya ilmiah dan mengurangi duplikasi atau pengulangan penelitian yang sama, (b) pelestarian jangka panjang untuk data penelitian (c) efisiensi biaya (d) validasi dari hasil penelitian (e) data di pergunakan kembali untuk penelitian selanjutnya. Mengacu pada pendapat Hosain et all (2016) bahwa komunikasi ilmiah yang dibangun atas dukungan perpustakaan lewat open data penelitian dapat meningkatkan aksesibilitas data penelitian, mengurangi duplikasi dan menghemat biaya.

Koltay (2019) peneliti membutuhkan dukungan terkait data untuk seluruh siklus hidup data penelitian mulai dari perencanaan, pengorganisasian, pendokumentasian, berbagi, dan pelestarian kumpulan data. Mereka juga dapat meminta nasihat tentang hak cipta, masalah perizinan dan kekayaan intelektual. Untuk memenuhi kebutuhan terkait data penelitian dan lainnya, perpustakaan tidak harus terlibat dalam interaksi dengan peneliti itu sendiri, tetapi juga harus mengidentifikasi dan bekerja sama dengan memberikan dukungan penyediaan layanan. Perpustakaan dan pustakawan, penting untuk memahami bahwa perannya sangat penting dalam memecahkan beberapa masalah terkait data penelitian. Untuk menentukan tempat yang tepat dalam proses penyimpanan data, semua pustakawan harus memperoleh pemahaman konseptual tentang data, dan juga meningkatkan keterampilan dan kemampuan untuk menemukan, mengekstrak, mengumpulkan, membersihkan, mengatur, menganalisis, dan menyajikan data. Layanan terkait data, penting diketahui, bagaimana peneliti memandang perpustakaan. Hal ini bermanfaat bagi pustakawan untuk menghargai peran perpustakaan tanpa melebih-lebihkannya. Sehubungan dengan pengelolaan data mengharuskan pustakawan untuk memperbaiki diri 
dan mendapatkan apresiasi terhadap masalah teknis dan sosial terkait dengan pengelolaan data penelitian. Pustakawan juga harus mendemonstrasikan dan berkomunikasi tentang layanan data penelitian layanan yang dapat ditawarkan perpustakaan. Pustakawan juga harus memahami bahwa meringankan beban teknis dan administratif peneliti adalah hal yang baik, namun demikian jangan melupakan pekerjaan inti perpustakaan dan harus fokus dan intensif terhadap pengelolaan perpustakaan, serta memahami keuntungan dengan memberikan layanan terkait data penelitian dan mendapatkan dukungan dari seluruh staf perpustakaan. Analisa Koltay (2019) bahwa membangun kumnikasi ilmiah dapat dilakukan apabila pustakawan yang ada di perpustakaan mempunyai kemampuan untuk menelusur daya, mengekstrak, mengumpulkan, membersihkan, mengatur, menganalisis, dan menyajikan data penelitian.

Liah ((2017) perpustakaan mendorong akses terbuka ke pengetahuan dapat mempercepat pembangunan ekonomi, membangun hubungan yang lebih kuat antara penyedia informasi dan masyarakat luas. Dukungan yang diberikan perpustakaan melalui diseminasi data penelitian melalui layanan referensi, jejaring sosial, situs web, milis dan online public access cataloging dapat meningkatkan komunikasi ilmiah. Hanneke and Link. (2019) dukungan perpustakaan dalam pengembangan open data adalah meningkatkan layanan berbagi data penelitian yang bertujuan untuk meningkatkan komunikasi ilmiah. Pustakawan yang bertugas di perpustakaan membuat visualisasi data untuk keperluan berbagi data penelitian kepada masyarakat serta mempromosikan repositori kelembagaan.

Shelly \& Jackson (2018) bahwa dukungan utama yang diberikan perpustakaan dalam membangun komunikasi ilmiah adalah membuat meta data dan menyimpan data dalam repositori. Melakukan pelatihan pengelolaan dan penyimpanan data penelitian untuk para peneliti dengan tujuan agar data penelitian yang dihasilkan dapat digunakan dan didesiminasikan untuk penelitian lebih lanjut. Sementara Charbonneau (2013) dukungan yang diberikan perpustakaan dalam membangun komunikasi ilmiah dengan menjadi pelopor dalam pengembangan sistem, proses berbagi data penelitian, proaktif dan responsif dalam pengelolaan data penelitian. Perpustakaan juga menjalankan fungsi sebagai penasehat, pelatih, serta mendukung peneliti dalam pengelolaan data penelitian yaitu sebagai sebagai kreator, pengumpul, pengelola dan pemakai data penelitian. 


\section{KESIMPULAN}

Berdasarkan hasil dan pembahasan dapat dismpulkan bahwa untuk meningkatkan komunikasi ilmiah di perpustakaan lembaga riset diperlukan adanya kebijakan open data penelitian. Kebijakan yang diterapkan memuat elemem yaitu rencana penegeloaan data dan proses berbagi data penelitian, memastikan datanya dapat diakses, penyimpanan data dalam repositori dan memastikan data dapat diakses dalam jangka waktu tertentu. Perpustakaan menjadi pelopor gerakan open data penelitian dengan memberikan layanan konsultasi untuk analisis data, penggalian data penelitian, layanan kurasi data, menganalisis dan memvisualisasikan data, serta menyelamatkan data penelitian dalam jangka waktu yang lama. Dukungan utama yang diberikan perpustakaan dalam membangun komunikasi ilmiah adalah membuat meta data dan menyimpan data dalam repositori. Memberikan pelatihan pengelolaan dan penyimpanan data penelitian untuk para peneliti dengan tujuan agar data penelitian yang dihasilkan dapat digunakan dan didesiminasikan untuk penelitian lebih lanjut.

\section{DAFTAR RUJUKAN}

Ashiq, M., Usmani, M. H., \& Naeem, M. (2020). A systematic literature review on research data management practices and services. Global Knowledge, Memory and Communication, ahead-of-print(ahead-ofprint). doi:10.1108/gkmc-07-2020-0103. Diakes 3 Februari 2021, dari https://www.emerald.com/insight/content/doi/10.1108/GKMC-07-20200103/full/html

Borgerud, C. and Borglund, E. (2020). Open research data, an archival challenge?. Archival Science, (20), 279-302. https://doi.org/10.1007/s10502-020-09330-3. Diakses 29 Januari 2021, dari https://link.springer.com/content/pdf/10.1007/s10502-020-093303.pdf

Charbonneau. D.H. (2013). Strategies for data management engagement. Medical Reference Services Quarterly. 32(3): 365-374. Diakses 3 Februari 2021, dari https://www.tandfonline.com/doi/abs/10.1080/02763869.2013.807089

Cox, A. M., Kennan, M. A., Lyon, L., Pinfield, S. and Sbaffi, L. (2019). Maturing research data services and the transformation of academic libraries. Journal of Documentation, 75 (6), 14321462. https://doi.org/10.1108/JD-12-2018-0211. Diakses 30 Januari 2021, 
dari https://www.emerald.com/insight/content/doi/10.1108/JD-12-2018$0211 /$ full/html

DOAR (2021). The Directory of Open Access R e p o s i t o r i e s - O p e $n$ D O A R . http://www.opendoar.org/, Diakses 11 Januari 2021

Chiware, E. \& Mathe, Z. (2015). Academic libraries' role in research data management services: a South African perspective. South African Journal of Libraries and Information Science. 81(2), 2-10. Diakses 6 Februari 2021, dari https://sajlis.journals.ac.za/pub/article/view/1563

Chiware, E.R.T. (2020). Open research data in African academic and research libraries: a literature analysis. Library Management, 41(6/7), 383-399. Diakses 30 Januari 2021, dari https://www.emerald.com/insight/content/doi/10.1108/LM-02-20200027/full/html

Frederick, A. and Run, Y. (2019). The Role of Academic Libraries in Research Data Management: A Case in Ghanaian University Libraries. Open Access Library Journal, 6, 1-16. https://doi.org/10.4236/oalib.1105286. Diakses 5 Februari 2021, dari https://www.scirp.org/journal/paperinformation.aspx?paperid=91504

Grygoruk, D. (2018). Open data in scientific ommunication. Folia Forestalia Polonica, Series A - Forestry, 60 (3), 192-198. DOI: 10.2478/ffp-20180019. Diakses 6 Februari 2021, dari https://sciendo.com/article/10.2478/ffp-2018-0019

Hanneke, R. and Link, J. M. (2019). The complex nature of research dissemination practices among public health faculty researchers. J Med Libr Assoc, 107 (3),341-351. doi: 10.5195/jmla.2019.524. Diakses 6 Februari 2021, dari https://pubmed.ncbi.nlm.nih.gov/31258440/

Heidorn, P. B. (2011). The Emerging Role of Libraries in Data Curation and E-science. Journal of Library Administration, 51(7-8), 662672. doi:10.1080/01930826.2011.601269. Diakses 6 Februari 2021, dari https://www.tandfonline.com/doi/abs/10.1080/01930826.2011.60126

Hossain, M. A., Dwivedi, Y. K. \& Rana, N. P. (2016). State-of-the-art in open data research: Insights from existing literature and a research agenda. Journal of Organizational Computing and Electronic Commerce, 26:1-2, 14-40, DOI: 10.1080/10919392.2015.1124007. Diakses $11 \quad$ Januari 2021, dari https://www.tandfonline.com/doi/abs/10.1080/10919392.2015.1124007

Huston P., Edge VL., Bernier, E. (2019). Reaping the benefits of Open Data in public health. Can Commun Dis Rep ,45(11), 252-256. doi.org/10.14745/ccdr.vi45i10a01. Diakses 5 Februari 2021, dari https://www.ncbi.nlm.nih.gov/pmc/articles/PMC6781855/ 
Koltay T. (2019). Identifying new roles for academic libraries in supporting data-intensive research. Bibliosphere, (4),97-102. DOI: 10.20913/18153186-2019-4-97-102. Diakses 30 Januari 2021, dari DOI: 10.20913/1815-3186-2019-4-97-102

Lasthiotakis, H., Andrew, K. and Sa, C. (2015). Open science strategies in research policies: A comparative exploration of Canada, the US and the UK. Policy Futures in Education,13(8), 968-989. Diakses 6 Februari 2021, dari https://journals.sagepub.com/doi/pdf/10.1177/1478210315579983

Mauthner, N. S. and Odette, P. (2013). Open Access Digital Data Sharing: Principles, Policies and Practices. Social Epistemology, 27(1), 47-67, http://dx.doi.org/10.1080/02691728.2012.760663. Diakses 6 Februari 2021 , dari https://www.tandfonline.com/doi/abs/10.1080/02691728.2012.760663

OECD. (2015). Making Open Science a Reality. OECD Science, Technology and Industry Policy Papers, No. 25, OECD Publishing, Paris. http://dx.doi.org/10.1787/5jrs2f963zs1-en. Diakses 11 Januari 2021, dari https://www.oecd-ilibrary.org/science-andtechnology/making-open-science-a-reality_5jrs2f963zs1-en

Shelly, M. \& Jackson, M. (2018). Research data management compliance: is there a bigger role for university libraries? Journal of The Australian Library and Information Association, 67(4), 394-410. Diakses 11 Januari 2021, dari https://www.tandfonline.com/doi/full/10.1080/24750158.2018.1536690

Shonhe, L. (2017). A Literature Review of Information Dissemination Techniques in the 21st Century Era. Library Philosophy and Practice (ejournal). 1731. https://digitalcommons.unl.edu/libphilprac/1731 Diakses 6 Februari 2021, dari https://digitalcommons.unl.edu/libphilprac/1731/

Wessels, B., Finn, R., Wadhwa, K. and Sveinsdottir, T. (2017). Open Data and the Knowledge Society. Amsterdam University Press B.V. Diakses 3 Februari 2021 dari, https://library.oapen.org/bitstream/id/182859cf-f9d7-4136-8413a862804a72ed/625332.pdf

Yoon, D. (2017). The information science policy for the public open data of the national research institute. Cogent Business \& Management, 4:1, 1406321, DOI: 10.1080/23311975.2017.1406321. Diakses 11 Januari 2021, dari https://www.tandfonline.com/doi/full/10.1080/23311975.2017.1406321 
Yu, H. H. (2017). The role of academic libraries in research data service (RDS) provision. The Electronic Library, 35(4), 783797. doi:10.1108/el-10-2016-0233. Diakses 3 Februari 2021, dari https://www.emerald.com/insight/content/doi/10.1108/EL-10-20160233/full/html

Zuiderwijk, A., \& Janssen, M. (2014). Open data policies, their implementation and impact: A framework for comparison. Government Information Quarterly, 31(1), 17-29. doi:10.1016/j.giq.2013.04.003. Diakses $11 \quad$ Januari 2021, dari https://www.sciencedirect.com/science/article/abs/pii/S0740624X13001 202 